\title{
PERAN GURU BK DALAM PENYESUAIAN DIRI SISWA DENGAN LINGKUNGAN SEKOLAH BARU DI SMPN 1 KATINGAN TENGAH Chi Asmanasari \\ SMP Negeri 1 Katingan Tengah
}

\begin{abstract}
ABSTRAK
Penelitian ini bertujuan untuk mengetahui peran guru BK dalam penyesuaian diri siswa terhadap lingkungan sekolah baru di SMP Negeri 1 Katingan Tengah. Penelitian ini merupakn penelitian kualitatif, dengan mengambil lokasi di SMP Negeri 1 Katingan Tengah. Pengumpulan data dilakukan dengan observasi, wawancara/interview, dan dokumentasi. Analisis data yang digunakan menggunakan teori Milles dan Huberman dengan mereduksi data yang didapat kemudian menyajikan data ke dalam pola dan membuat kesimpulan dan verifikasi dari hasil tersebut. Hasil penelitian ini menunjukkan, bahwa guru BK SMP Negeri 1 Katingan Tengah memiliki peran yang penting dalam penyesuaian diri siswa terhadap lingkungan sekolah baru, yaitu dengan membagikan angket kebutuhan peserta didik, membuat program BK, membuat rencana pelaksanaan layanan (RPL), dan memberikan layanan bimbingan konseling berupa layanan bimbingan klasikal, bimbingan kelompok, konseling individual dan konseling kelompok.
\end{abstract}

Kata Kunci: penyesuaian diri siswa, lingkungan sekolah

\section{PENDAHULUAN}

Tujuan Pendidikan Nasional terdapat dalam pasal 3 Undang-undang No. 20 Tahun 2003 yang berbunyi: "Pendidikan nasional berfungsi mengembangkan kemampuan dan membentuk watak serta peradaban bangsa yang bermartabat dalam rangka mencerdaskan kehidupan bangsa, bertujuan untuk berkembangnya potensi peserta didik agar menjadi manusia yang beriman dan bertakwa kepada Tuhan Yang Maha Esa, berakhlak mulia, sehat, berilmu, cakap, kreatif, mandiri, dan menjadi warga negara yang demokratis serta bertanggung jawab."

Sekolah adalah sebuah lembaga yang dirancang untuk pengajaran siswa atau murid di bawah pengawasan pendidik atau guru. Salah satu guru yang berperan penting dalam perkembangan peserta didik di sekolah adalah guru BK.

Pelayanan bimbingan dan konseling di sekolah merupakan usaha membantu peserta didik dalam pengembangan kehidupan pribadi, kehidupan sosial, kegiatan belajar, serta perencanaan dan pengembangan karir.
Guru bimbingan dan konseling (BK) di sekolah melakukan berbagai upaya membantu siswa mencapai perkembangan sikap, perilaku yang sehat serta mengetahui perbedaan setiap siswa. Perkembangan siswa tidak lepas dari pengaruh lingkungan, baik fisik, psikis maupun sosial yang selalu berubah dan memengaruhi gaya hidup (life style).

Upaya-upaya yang dilakukan guru bimbingan dan konseling di sekolah tersebut sangat penting sebagaimana dikemukakan oleh Tohirin (2007: 35) bahwa keberadaan guru BK adalah untuk mencapai perkembangan yang optimal pada siswa yang dibimbing. Hal ini berarti bahwa guru BK di sekolah perlu melakukan berbagai upaya membantu siswa agar dapat mengembangkan dirinya secara optimal sesuai dengan potensi atau kapasitasnya dan agar dapat berkembang sesuai dengan kondisi lingkungannya.

Berdasarkan wawancara yang dilakukan peneliti pada beberapa guru SMP Negeri 1 Katingan Tengah, diperoleh informasi bahwa peran guru bimbingan dan 
Jurnal Inovasi BK,Volume 1, Nomor 2 Desember 2019 konseling dalam penyesuaian diri siswa diwujudkan dalam bentuk membantu penyesuaian terhadap diri sendiri, penyesuaian terhadap guru, penyesuaian terhadap siswa lainnya, penyesuaian diri terhadap materi dan kegiatan belajar serta penyesuaian diri terhadap lingkungan sekolah. Hasil dari wawancara dengan siswa G.J.S.salah satu siswa di SMP Negeri Katingan Tengah mengatakan dia kurang percaya diri dalam penyesuaian diri disekolah karna dia anaknya agak sedikit pemalu. Disinilah guru BK membantu dia dengan mengadakan layanan-layanan yang mana memberikan informasi guna mengurangi sifat pemalunya.

Berdasarkan penelitian terdahulu yang dilakukan oleh Rizqiyah, M. (2017) yang berjudul "Peranan Guru Bk Dalam Membantu Penyesuaian Diri Siswa Baru Di Smp It Abu Bakar Yogyakarta”. Hasil penelitiannya menunjukkan bahawa menunjukkan, bahwa guru BK dalam membantu penyesuaiandiri siswa baru, memiliki peranan yang penting, yaitu sebagai informator, organisator, motivator, director/pengarah, inisiator, transmitter, fasilitator, mediator dan evaluator.

Berdasarkan uraian tersebut, maka peneliti tertarik untuk lebih mengetahui secara mendalam tentang peranan guru bimbingan dan konseling dalam membantu penyesuaian diri siswa baru di sekolah baru dalam sebuah penelitian dengan judul "Peran Guru BK dalam Penyesuaian Diri Siswa dengan lingkungan sekolah Baru di SMP Negeri 1 Katingan Tengahi”. Tujuan penelitian ini adalah untuk mengetahui sejauh mana guru bimbingan dan konseling berperan dalam membantu penyesuaian diri siswa dengan lingkungan sekolah baru di SMP Negeri 1 Katingan Tengah.

\section{METODE}

Pada metode penelitian ini peneliti menggunakan penelitian pendekatan deskrptif kualitatif yang mana dengan melihat, merasakan mengamati dan sebagainya suatu obyek dan subyek. Menurut Machfudz (dalam Rizqiyah, 2016) Penelitian deskriptif adalah penelitian yang bermaksud untuk membuat deskripsi, gambaran atau lukisan secara sistematis, faktual dan akurat mengenai fakta-fakta, sifat-sifat serta hubungan antar fenomena yang diselidiki. maka peneliti menggunakan bahwa penelitian atau pendekatan yang akan digunakan dalam penelitian ini yaitu pendekatan deskriptif kulitatif, karena seperti yang dijelaskan di atas bahwa data deskriptif adalah data yang dapat diamati.

Metode pengambilan data dalam penelitian ini adalah observasi, wawancara dan dokumentasi. Dalam metode observasi yang digunakan adalah observasi non partisipan, yaitu dalam proses kegiatan mengadakan pengamatan langsung di SMP Negeri 1 Katingan Tengah, namun penulis tidak secara langsung berpartisipasi atau ikut serta dalam kegiatan (Hadari Nawawi, 2000). Dalam metode wawancara, jenis wawancara digunakan adalah bebas terpimpin, pedoman wawancara yang hanya berupa garis besarnya saja tentang hal-hal yang ditanyakan dan sesuai dengan data yang diteliti (Ahmad Tanzeh, 2011).

Dalam metode dokumentasi, digunakan untuk mendapatkan sejumlah data, yaitu tentang letak geografis, sejarah berdiri dan perkembangan sekolah, visi-misi dan tujuan sekolah, struktur organisasi, sarana dan prasarana, keadaan dan kondisi guru dan siswa, serta data terkait dengan peran guru BK dalam penyesuaian diri siswa dengan lingkungan sekolah baru.

Data yang telah terkumpul pada penelitian ini akan dianalisis sesuai dengan tahapan menurut Miles \& Huberman (Sugiono, 2016), yaitu reduksi data, penyajian data dan penarikan Kesimpulan.

\section{HASIL DAN PEMBAHASAN}

Berdasarkan data yang telah dikumpulkan melalui metode wawancara dan dokumentasi, peran guru BK dalam membantu penyesuaiandiri siswa dengan 
lingkungan sekolah baru di SMP Negeri 1 Katingan Tengah dapat diuraikan dalam beberapa kegiatan yaitu, (1) membagikan angket kebutuhan peserta didik, (2) membuat program BK, (3) membuat rencana pelaksanaan layanan (RPL), (4) memberikan layanan bimbingan konseling, dan (5) melakukan evaluasi dan tindak lanjut terhadap masalah penyesuaian diri siswa.

Guru BK pada tahun ajaran baru selalu memberikan AKPD kepada seluruh siswa baru dan juga siswa yang telah lama. Pemberian AKPD ini bertujuan untuk mendapatkan data yang akan dijadikan dasar dalam menyusun program BK. Kepedulian dan sikap proaktif guru BK tersebut menunjukkan bahwa guru BK bertanggung jawab dalam mengumpulkan data tentang siswa, karena data ini penting dalam pemberian bantuan bagi siswa agar siswa tidak menemui kendala yang dapat menghambat perkembangannya.

Penyusunan sebuah program adalah agar seluruh kegiatan dapat terorganisasi dan terkoordinasi secara sistematis, sehingga dapat berjalan dengan lancar, efisien, dan efektif kearah pencapaian suatu tujuan. RPL dibuat harus berdasarkan kebutuhan peserta didik. Tujuan dari penyusunan RPL agar setiap langkah kegiatan layanan akan lebih terarah dan lebih jelas

Berbekal AKPD dan pemahaman yang tentang siswa, guru BK lebih mudah dalam memberikan bantuan penanganan permasalahan siswa, baik penyesuaian diri dalam bidang pribadi, social, karir dan belajar. Bantuan yang diberi berupa layanan BK yang bersifat pencegahan diwujudkan oleh guru BK dalam bentuk pemberian layanan informasi dan layanan orientasi kepada siswa baru melalui kegiatan bimbingan klasikal atau bimbingan kelompok, sedangkan layanan yang bersifat pengentasan dapat di wujudkan dengan melakukan layanan konseling individual atau konseling kelompok.

Jika menurut hasil evaluasi menunjukkan bahwa permasalahan penyesuaian diri siswa dapat teratasi, maka permasalahan itu dianggap tuntas. Sebaliknya, jika belum teratasi maka perlu adanya upaya pemberian layanan lainnya yang dalam BK disebut tindak lanjut.

Guru BK memiliki peran besar dalam membantu penyesuaian diri siswa dengan lingkungan sekolah baru. Guru BK perlu memastikan bahwa peserta didiknya tidak mengalami masalah penyesuaian diri yang dapat mengakibatkan terjadinya konflik. Peran yang telah dilakukan oleh guru BK kepada siswa guna membantu siswa dalam penyesuian diri dengan lingkungan sekolah baru menggunakan beberapa layanan diantaranya layanan bimbingan klasikal, bimbingan kelompok, Konseling individual dan konseling kelompok.

Selanjutnya guru BK juga melakukan evaluasi dan tindak lanjut terhadap layanan yang telah dilaksanakan dan merencanakan layanan berikutnya jika masalah penyesuaian diri siswa belum teratasi. Upaya-upaya tersebut sebagaimana pendapat Sukardi (2000: 56) yang mengemukakan bahwa guru bimbingan dan konseling adalah sebagai pelaksana utama, tenaga inti dan ahli, dalam penyelenggaraan bimbingan dan konseling di sekolah memiliki tugas sebagai guru BK pada poin a) mengumpulkan data dan menyusun program $\mathrm{BK}, \mathrm{b})$ melaksanakan segenap layanan BK, dan c) melaksanakan tindak lanjut berdasarkan hasil penilaian terhadap layanan yang telah dilaksanakan.

Guru BK di SMP Negeri 1 Katingan Tengah berharap dengan adanya bantuan berupa layanan yang diberikannya kepada siswa dalam menyesuikan diri dengan lingkungan sekolah baru dapat mengurangi 
Jurnal Inovasi BK,Volume 1, Nomor 2 Desember 2019

hambatan dan rintangan yang mengganggu tumbuh kembang siswanya di sekolah.

\section{KESIMPULAN}

Berdasarkan pemaparan dari hasil pembahasan diatas, ditemukan bahwa guru BK di SMP Negeri 1 Katingan Tengah melakukan beberapa kegiatan dalam perannya membantu siswa menyesuaikan diri yaitu dengan membagikan angket kebutuhan peserta didik, membuat program BK, membuat rencana pelaksanaan layanan (RPL), dan memberikan layanan bimbingan konseling berupa layanan bimbingan klasikal, bimbingan kelompok, konseling individual dan konseling kelompok.

\section{DAFTAR PUSTAKA}

Ihsanti, E. F., Sunan, K. U., \& MI, K. G. K. Bimbingan Kelompok Sebagai Layanan Dalam Membantu Siswa Menyesuaikan Diri Dengan Lingkungan Baru.

Lestari, S., Sugiharto, D. Y. P., \& Wibowo, M. E. (2013). Meningkatkan Penyesuain Diri Terhadap Program Keahlian pada Siswa Melalui Layanan Bimbingan Kelompok. Indonesian Journal of Guidance and Counseling: Theory and Application, 2(4).

Rahmawati, L. N. N. (2015). Penanganan konselor terhadap masalah penyesuaian diri siswa SMA Negeri 3 Tuban. Jurnal BK Unesa, 5(1).

Rizqiyah, M. (2017). Peranan Guru Bk Dalam Membantu Penyesuaian Diri Siswa Baru Di Smp It Abu Bakar Yogyakarta. Hisbah: Jurnal Bimbingan Konseling dan Dakwah Islam, 14(2).

Rosidah, A. (2016). Bimbingan kelompok melalui teknik problem solving untuk meningkatkan penyesuaian diri siswa terisolir. Jurnal Fokus Konseling, 2(2).
Sa'adah, H. (2010). Peran bimbingan pribadi-sosial terhadap penyesuaian diri siswa di Madrasah Aliyah Negeri Babat Lamongan (Doctoral dissertation, IAIN Sunan Ampel Surabaya).

Salmiwati, S. (2017). Peran Bimbingan dan Konseling melalui Layanan Informasi dalam Membantu Penyesuaian Diri Mahasiswa Baru. Jurnal Al-Taujih: Bingkai Bimbingan dan Konseling Islami, 3(1), 52-65.

Sugiono. (2016). Metode Penelitian: Kuantitatif, Kualitatif dan R\&D. Bandung: Alfabeta.

Sukardi, Dewa Ketut. (2000). Pengantar Pelaksanaan Program Bimbingan dan Konseling di Sekolah. Jakarta : Rineka Cipta.

Tohirin. (2007). Bimbingan dan Konseling di Sekolah dan Madrasah (berbasis Integrasi). Jakarta: Raja Grafindo Persada.

Undang-Undang No. 20 Tahun 2003 Tentang Sistem Pendidikan Nasional. Pasal 3. 